\title{
All Going According to Plan? The Armed Forces and Government in Myanmar ${ }^{1}$
}

\section{ANDREW SELTH}

It has become the conventional wisdom that the transition from authoritarian rule to a more democratic form of government in Myanmar was due to the efforts of Aung San Suu Kyi and the National League for Democracy, the pressures applied against the military regime by Western democracies and belated recognition by the ruling generals that Myanmar could not continue down the path of political and economic isolation. This narrative suits many of the key actors in this drama, but it denies independent agency to the most important player of all, namely the country's armed forces. The paradigm shift which has occurred in the country's political landscape over the past decade can more accurately be described as the result of a long-term plan drawn up by Myanmar's military leadership, which surrendered absolute power in a calculated move to advance its own agenda through the controlled transition to a "disciplined democracy".

Keywords: Myanmar, Burma, Tatmadaw, Aung San Suu Kyi, democratization.

It has become the conventional wisdom in the West and elsewhere that the peaceful transition from authoritarian rule to a more democratic form of government in Myanmar has taken place because of the tireless efforts of Aung San Suu Kyi and the

Andrew SELth is an Adjunct Associate Professor at the Griffith Asia Institute, Griffith University. Postal address: Griffith Asia Institute, 170 Kessels Road, Nathan, Brisbane, Queensland 4111, Australia; email: a.selth@griffith.edu.au. 
National League for Democracy (NLD), the diplomatic and economic pressures brought to bear on the former military regime by the international community, and belated recognition by the generals that Myanmar could not continue down the path of political and economic isolation without becoming weaker and more vulnerable. This narrative suits many of the key actors in this drama, in particular Aung San Suu Kyi's supporters, foreign politicians and human rights campaigners. Indeed, many of them have been quick to take credit for what appears to be a remarkable and, considering the failed democratic transitions seen elsewhere in the world, rare success story. ${ }^{2}$ This interpretation of events is not entirely incorrect. However, it denies independent agency to the most important player of all, namely Myanmar's armed forces (Tatmadaw).

There is another way of looking at the extraordinary paradigm shift which has occurred in Myanmar's political landscape over the past decade or so. That is, by recognizing the key developments during this period as steps in a long-term plan drawn up some 15 years ago by the country's military leadership, which willingly surrendered absolute power in order to advance its own agenda and achieve a number of specific ends. If this explanation of the democratic transition in Myanmar is accepted, then it throws a different light on the advent of the NLD government and its relations with the Tatmadaw. It also suggests that the international community can only play a limited role in influencing the country's future transition from a "disciplined democracy" to a genuine democracy. As in the past, that process will be decided by actors within Myanmar, not least the armed forces.

\section{Stepping Back}

When Senior General Than Shwe and the ruling State Peace and Development Council (SPDC) held national elections in November 2010, and handed over government to President Thein Sein in March 2011, they were not forced to do so. As the most powerful armed force in the land, the Tatmadaw did not fear a major military defeat, or internal unrest. No insurgent group or political movement had the capacity to seriously threaten the government in Naypyidaw. If they had chosen to do so, the generals could have continued to resist popular demands for political change, including by Aung San Suu Kyi and the NLD, albeit not without difficulty. Nor, despite the claims made by some foreign politicians and activist organizations, was the regime overly concerned by the diplomatic pressures and 
economic sanctions that had been applied by the Western democracies and various international organizations since the 1988 pro-democracy uprising. ${ }^{3}$ While some of these measures may have had a modest impact, the regime had successfully sidestepped sanctions by cultivating relations with the Association of Southeast Asian Nations (ASEAN) and major powers like China, India and Russia.

Granted, the ruling council was very unpopular and faced some serious domestic problems, but when it handed over power to Thein Sein it was firmly entrenched in power. Indeed, by almost every measure, the military regime in 2011 was stronger than it had been at any time since General Ne Win's coup d'etat in 1962. The SPDC's readiness to relax its grip on power and allow a more liberal form of government to evolve in Myanmar was not a sign of weakness and insecurity, as often claimed by its critics, but of strength and confidence. It was also part of a carefully considered long-term plan.

As far as can be assessed, around 2002 the SPDC concluded that it was in Myanmar's best interests, and the Tatmadaw's, to embrace change. ${ }^{4}$ In economic, technical, military and other ways, the country had fallen behind its regional neighbours and the rest of the world. In order for Myanmar to maintain its independence, security, economic growth and national prestige, the country needed to become more open, more modern, more prosperous and more respected internationally. This was also seen as a way of letting some of the steam out of the pressure cooker that was Myanmar society, which for decades had been bottling up demands for greater personal freedoms, increased access to the outside world and more foreign goods and services. At the same time, the Tatmadaw wanted to shed some of its responsibilities for the minutiae of government and to become truly professional (the armed forces' Commanderin-Chief Senior General Min Aung Hlaing preferred the term "a standard army"), armed with modern weapons and equipment. ${ }^{5}$ It also hoped that it might once again be able to forge relationships with the armed forces of the Western democracies and, eventually, gain access to their superior technology.

To achieve all these ends, Myanmar had to make the transition from direct military rule to a more democratic form of government. The generals were not prepared to hand over power completely, as they did not feel they could put their trust, and the fate of the country, in an inexperienced, fractious and potentially hostile civilian administration. This had happened during the so-called "democratic era" (1948-62), with what they saw as disastrous 
results. The generals were also acutely conscious of failed political transitions in the Middle East, North Africa and elsewhere in the world, and were determined that such crises would not occur in Myanmar. However, a limited, carefully controlled, top-down process of gradual democratization promised to deliver the outcomes they sought. Accordingly, the armed forces leadership devised a sevenpoint "roadmap" that envisaged the "step-by-step and systematic" implementation of a transition to what was described as a "disciplineflourishing democracy". This plan was announced by Prime Minister Khin Nyunt in August 2003. ${ }^{6}$

As later explained by SPDC spokesmen, the first step in this plan was the recall of the National Convention, which had been formed in 1992 to draft a new constitution, but suspended after the NLD representatives walked out in 1996. The second step was the implementation of a scheme to introduce what was called a "genuine and disciplined" democratic system. The third step was the drafting of a new constitution in accordance with the principles laid down by the National Convention. The fourth step was the holding of a national referendum to endorse a draft constitution. The fifth step was the election of the various legislative bodies (Pyitthu Hluttaws) that were to be outlined in the new national charter. The sixth step was to convene the provincial (State and Region) and national assemblies. The last step in the SPDC's roadmap was described as the construction of "a modern, developed and democratic state" by elected representatives, the government and "other central organs formed by the Hluttaw". ${ }^{7}$

Setting aside questions raised by the nature of this process, and the final result, it can be argued that over the next eight years the military regime did precisely what it had promised to do. Despite pressures to amend or abandon the roadmap, from both within and outside Myanmar, it was followed closely. Military spokesmen emphasized that it was the only viable path to political reform. A new constitution, ostensibly drafted by the National Convention but clearly reflecting provisions pre-determined by the military leadership, was put to a referendum in 2008. According to figures later published by the SPDC, it was endorsed by 92.4 per cent of the country's 22.7 million eligible voters. ${ }^{8}$ Elections for both provincial and national legislative assemblies were held on 7 November 2010. In part because the NLD boycotted the poll, the result was a landslide victory for the military-backed Union Solidarity and Development Party (USDP), which won almost 80 per cent of the seats contested at the national level. All new members of parliament 
(MP) were sworn in the following January, and in March 2011 the combined houses elected former general Thein Sein as president.

Continuing this process, by-elections were held on 1 April 2012 to fill 48 seats left vacant after MPs had resigned to take up ministerial appointments, or died. The NLD, which was re-registered for the elections in December 2011, claimed that fraud and rules violations were widespread, but the party still won 43 of the 45 seats available on the day. ${ }^{9}$ One successful candidate was the party's leader, Aung San Suu Kyi. On 8 November 2015, another general election for both provincial and national assemblies was held. By all accounts, it was reasonably free and fair. ${ }^{10}$ The result was a landslide for the NLD, which secured 390 of the 491 seats (or 79.4 per cent) contested at the Union level. (The NLD also secured 476 of the 629 seats in the 14 State and Region assemblies). ${ }^{11}$ The NLD's majority in both houses at the national level ensured that it could elect the new president. Under the 2008 Constitution, Aung San Suu Kyi could not take this position, as her two sons were foreign nationals, but the post of state counsellor was created especially for her. Even before the elections she had made it plain that, if denied the top job, she would consider herself "above the president", and act as Myanmar's de facto leader. ${ }^{12}$

Critical to the seven-step roadmap was the promulgation of a new constitution, which set out the basis for the Tatmadaw's continuing role in national politics. One quarter of the seats in all provincial and national assemblies were reserved for serving military officers. This effectively gave the armed forces the power of veto over any proposed constitutional amendments. The Ministries of Defence, Home Affairs and Border Affairs were reserved for senior military officers appointed by the commander-in-chief. This meant that the military leadership not only controlled the armed forces but also the police force, the intelligence agencies, the national bureaucracy and immigration policy. In addition, the Tatmadaw dominated the National Defence and Security Council (NDSC), a potentially powerful body which could declare states of emergency and which, in certain circumstances, could hand control of the country back to the armed forces. In its administration and operations, the Tatmadaw was made completely independent from the government and parliament. In addition, members of the armed forces were granted special legal status.

With their position and power thus protected, the generals could step back from day-to-day government confident that they still managed the country's coercive apparatus, and that security and other critical 
aspects of Myanmar's internal affairs were largely under their control. These arrangements also meant that, despite the transition to a "disciplined democracy", the Tatmadaw remained the most powerful political institution in Myanmar. It could not be weakened, or its official role diminished, by a civilian administration without changing the 2008 Constitution and that was not possible without the agreement of more than 75 per cent of the Union parliament. As Robert Taylor wrote in 2015, "Only the army can end its own role in Myanmar's politics, and that decision is dependent on its perception of the civilian political elite's ability to manage the future." ${ }^{13} \mathrm{He}$ might have added, "and protect the Tatmadaw as a national institution".

\section{Anticipating Change}

There were other factors involved, and in practice the process was not quite as smooth or straightforward as suggested by the brief outline given above. However, the fact remains that this remarkable transformation of Myanmar's political landscape in barely a decade occurred because the armed forces' high command conceived it, planned it and ultimately managed it. If they had wanted to do so, the generals could have intervened at any stage of the process and made adjustments. For example, the 2015 elections were relatively free and fair, and produced a reasonably accurate result, because the leaders of the armed forces permitted them to occur and did not interfere. It may not have been easy, or without certain consequences, but if they had wanted to they could have ensured that the elections were cancelled, postponed or manipulated to produce a different outcome. After all, the generals had interfered in polls before, either to ignore the final result, as occurred in 1990 after the NLD resoundingly won the elections that year, or to ensure they obtained the result they wanted, as seen in the 2008 constitutional referendum.

Given the wide geographical distribution of military bases in Myanmar, the Tatmadaw's extensive intelligence apparatus and the regime's control of the country's internal affairs through the Home Ministry's General Administration Department (GAD), the armed forces high command would have known well in advance of the 2015 poll that a free and fair election would result in a decisive victory for Aung San Suu Kyi and the NLD. The final statistics may have come as a surprise (before the poll some respected foreign analysts were questioning whether the party could achieve 
a landslide) but the outcome could not have been in doubt. ${ }^{14}$ This being the case, it can be assumed that, well before the election took place, the armed forces, led by Senior General Than Shwe, took a collective decision to accept the results. There is no tradition in Myanmar of sharing political power, but the generals must also have faced the prospect of negotiating responsibility for the future governance of the country with Aung San Suu Kyi, whether or not she became president.

The massive show of popular support for Aung San Suu Kyi and the NLD on 8 November 2015 gave them enormous moral authority and a strong bargaining position. However, despite popular expectations, both within and outside Myanmar, this did not guarantee them a free hand to form a government and shape the country's future. Under the arrangements put in place by the former military regime, that could only be done in close cooperation with the armed forces. In that regard, both the Tatmadaw's leadership and Aung San Suu Kyi knew that they would not gain anything from a direct confrontation. That would only cause internal turmoil, hurt the Myanmar people and see Myanmar condemned internationally. If it got out of hand, such a clash of wills would inevitably slow down the democratic transition process and, in certain circumstances, even halt it. That would benefit no one, least of all Aung San Suu Kyi and the NLD.

Aung San Suu Kyi is known to have held at least three meetings with Senior General Min Aung Hlaing following the 2015 election. The subjects discussed have not been revealed, but it can be assumed that they included her wish to become president and future power sharing arrangements. ${ }^{15}$ Her presidential bid was doomed from the start, but a modus vivendi seems to have been reached between Aung San Suu Kyi and Senior General Min Aung Hlaing that allowed them both to move forward. ${ }^{16}$ It was never going to be an equal or comfortable arrangement, but with both sides keeping to their main areas of responsibility it seems to have worked, after a fashion. ${ }^{17}$ It is hard to escape the conclusion, however, that the armed forces have successfully retained the whip hand. After its first year in office, one observer was prompted to write that "The most disappointing feature of the NLD government is that it time and time again appeared to align itself with military interest ... either through supportive statements or abject silence, without making clear any difference between their objectives and interest."18 
Even so, implementing the Tatmadaw's master plan carried certain risks. The generals could not foresee every eventuality. Once a process of democratic transition is set in train, it tends to develop a life of its own. As the French political philosopher Alexis de Tocqueville wrote in 1856, "The most dangerous moment for a bad government is when it begins to reform." 19 In Myanmar's case, the generals probably did not expect Thein Sein's reform programme to be as broad or to be implemented as quickly as it was. Under ambitious Speaker Thura Shwe Mann, the new legislature showed a surprising degree of independence. The creation of the position of state counsellor in 2016 appears to have taken the generals by surprise. There was the possibility that, by allowing a more liberal administration to emerge, the population would demand even greater freedoms and take to the streets to obtain them. Also, the prospect of a more enlightened military regime could have encouraged the international community to apply even greater pressure for a full democracy, rather than welcome (with reservations) the advent of a controlled, top-down transition to a quasi-democracy, as in fact occurred.

\section{Maintaining Control}

The NLD's overwhelming majority in the national parliament has opened up a range of possibilities, and given it certain public relations benefits, but Aung San Suu Kyi's freedom of action and ability to work the levers of power are heavily circumscribed. Indeed, the 2008 Constitution could have been written with the current situation in mind. The Tatmadaw chiefs clearly anticipated the possibility that the armed forces might one day be faced with a potentially hostile parliament. This was precisely why they built in various measures to protect its position and core interests, and to guarantee its continuing central role in national affairs. That is also why the generals now view the Constitution as "the main or mother law" of Myanmar, which they are determined to safeguard. ${ }^{20}$ With this in mind, the Tatmadaw has firmly opposed all moves by the NLD to amend the Constitution, in particular those provisions that cover the presidency and the armed forces' guaranteed 25 per cent of the seats in all assemblies.

Future constitutional amendments have not been ruled out, but Tatmadaw spokesmen have consistently stated that changes will only be permitted when Myanmar's democracy has "matured". ${ }^{21}$ The generals will decide when that stage has been reached. Faced with 
this situation, the NLD has tried to find ways around the charter's more restrictive provisions. It is a long and detailed document, clearly written in an attempt to cover all contingencies, but the NLD has managed to find some loopholes which it can exploit. The most notable example is the party's use of its parliamentary majority to create the position of state counsellor, in the face of strong opposition from the military bloc. ${ }^{22}$ Aung San Suu Kyi's claimed status "above the president" is in direct violation of the Constitution, which specifically states that the president "takes precedence over all other persons" in Myanmar. ${ }^{23}$ This may lead to a challenge in the Constitutional Tribunal, but it is elected proportionally by President Htin Kyaw (who is an Aung San Suu Kyi loyalist), and the two houses of parliament, both of which are dominated by the NLD.

Another way in which Aung San Suu Kyi has tried to outflank the Tatmadaw was to appoint her own National Security Advisor (NSA) in January 2017. The post, filled by a former diplomat, Thaung Tun, was created "in order to advise the president and the Union Government on internal and external threats by assessing situations from a strategic point of view". ${ }^{24}$ The nature of these threats, and how the NSA coordinates his advice with strategic intelligence assessments provided by the Tatmadaw and Ministry of Foreign Affairs, was not specified. ${ }^{25}$ Aung San Suu Kyi has also refused requests by the USDP and several of the smaller parties to convene a meeting of the NDSC to discuss a range of internal security problems, not least the bitter conflicts in Myanmar's northern provinces and Rakhine State. ${ }^{26}$ Her refusal appears to stem from a suspicion that, given the Council's predominantly military membership, Senior General Min Aung Hlaing could use such a meeting to pursue his own agenda and claim the NDSC's endorsement.

Some observers have even suggested that the NDSC might be used by the armed forces to mount a takeover of the government. ${ }^{27}$ However, if the generals were seriously concerned about any of the NLD's policies, and wanted to change them, they do not need to intervene directly. There are other ways in which they can influence developments and exert pressure on Aung San Suu Kyi's government, if they wished to do so.

There are 15 governments in Myanmar: the national government in Naypyidaw and 14 State and Region assemblies. There are also a number of special administrative zones, covering small ethnic groups like the Wa and Naga. However, in practice the administration 
of Myanmar is highly centralized. The Constitution was designed to keep control of the country in the hands of a small number of officials. For example, the States and Regions elect their own assemblies but all chief ministers are appointed by the president and their responsibilities are quite limited. The Constitution also gives wide-ranging powers to the commander-in-chief of the armed forces. As noted above, he appoints the Ministers of Defence, Home Affairs and Border Affairs. Also, through the GAD, which was created by General Ne Win in 1972, the commander-in-chief has direct, centralized control over government administration down to the lowest level. All State and Region civil services are also under GAD management. This situation gives the Tatmadaw considerable scope to influence government policies and actions. ${ }^{28}$

As Robert Taylor has observed, Myanmar's civil service has long been ineffective. ${ }^{29}$ After decades of a hierarchical command culture, answering to an authoritarian government, there is no tradition of public officials taking the initiative, challenging decisions or reporting failures. Many lack managerial expertise and operate through personal relationships rather than established bureaucratic procedures. Corruption is rife. In addition, when the NLD took office, over 80 per cent of senior civil service positions were occupied by former servicemen and women, raising the prospect of divided loyalties. ${ }^{30}$ For, as Renaud Egreteau has written, over decades the officer corps was socialized into believing that the Tatmadaw was the sole and uncontested embodiment of the state. ${ }^{31}$ After the 2015 elections, the senior ranks of the civil service pledged support for the NLD government, and a few officials were appointed to ministerial positions. However, there is still resistance to change in the bureaucracy and considerable potential for its manipulation by the armed forces.

The NLD has continued to allocate a large percentage of the national budget to defence (around 14 per cent in 2016). ${ }^{32}$ The Tatmadaw also receives funds from a range of off-budget sources and, under a 2011 law, is permitted to use other means to find the resources it needs to meet its responsibilities. Should the NLD try to put pressure on the Tatmadaw by reducing its share of central government expenditures, however, there is bound to be strong pushback from the generals. The military campaigns being conducted in Myanmar's west and north, for example, have already incurred significant operational costs. The role of the armed forces in the national economy has been gradually declining since 2011, as the Tatmadaw has given up some of its monopolies and its two main 
conglomerates, the Union of Myanmar Economic Holdings Ltd. and Myanmar Economic Corporation, have begun paying taxes. Should it wish to do so, however, the armed forces and their "capitalist cronies" (most of whom occupy influential positions) could exert considerable pressure on the government by exercising their economic power. ${ }^{33}$

Being independent in national security matters, the Tatmadaw has another powerful lever which it can use to exert pressure on the NLD government. One of the government's highest priorities is what Aung San Suu Kyi has dubbed the "21 $1^{\text {st }}$ Century Panglong" peace process, aimed at achieving a comprehensive settlement with about 20 ethnic armed groups. Yet, there is no hope of a ceasefire agreement, let alone a nation-wide peace settlement, without the full cooperation and support of the armed forces. Over the past year, the Tatmadaw has launched or renewed counter-insurgency campaigns against several ethnic armed groups in northern and eastern Myanmar. This heightened military activity has greatly complicated relations between the NLD government and the ethnic minorities. ${ }^{34}$ Senior General Min Aung Hlaing has also taken a hard line on issues like disarmament, demobilization, reintegration and security sector reform. ${ }^{35}$ The armed forces cannot control the national peace process, which involves many players at different levels, but they can significantly affect its progress and possible outcomes.

The NLD is also hostage to the Tatmadaw's activities in Rakhine State. After attacks by Muslim militants against three border guard posts in October 2016, army and police units conducted harsh "area clearance operations" against Rohingya communities. Further attacks by Muslim militants in August 2017 sparked a massive military reaction. There have been hundreds if not thousands of casualties and over 600,000 refugees have fled into Bangladesh. ${ }^{36}$ The brutal tactics employed by the security forces have left Aung San Suu Kyi and her government looking weak and ineffectual, if not worse. They have been subject to scathing international criticisms. Even Aung San Suu Kyi's fellow Nobel laureates have accused her of failing the most fundamental test of humanity. ${ }^{37}$ To answer these charges, and protect her government's reputation, the state counsellor is largely dependent on the willingness of the Tatmadaw to moderate its behaviour. The generals' influence over her government can be gauged by the fact that she has repeatedly declined invitations to criticize the security forces. Indeed, she has protected them, for example, by refusing to permit a United Nations fact-finding mission 
to visit Myanmar and investigate charges of widespread human rights abuses in Rakhine State. ${ }^{38}$

Last, but not least, the Tatmadaw enjoys a monopoly of the means of applying state force in Myanmar. The commander-in-chief commands the estimated 350,000-strong army, navy and air force. ${ }^{39}$ In recent years, all three services have been strengthened with modern arms and equipment. They have become more proficient at conducting conventional warfare, including joint operations. Also, through the Home Affairs Minister, a senior army officer who he appoints, the commander-in-chief can deploy the estimated 85,000 strong Myanmar Police Force, which has over 30 well-armed security battalions. ${ }^{40}$ Many of these units are made up of former soldiers and are combat trained. In extremis, the commander-in-chief can also call upon other elements of the so-called "Defence Services", which interpreted broadly include militia units and other paramilitary forces, the Fire Services Department and the Myanmar Red Cross. Should he ever choose to exercise it, the commander-in-chief thus commands the ultimate sanction against any political leader or government that challenges the Tatmadaw's self-appointed role.

Through all these means, the generals are able to exercise a powerful influence over Myanmar's internal affairs, short of direct intervention. In conducting government, and considering the country's immediate future, Aung San Suu Kyi and the NLD need to make due allowance for this reality, and to maintain some kind of working relationship with the military leadership. To reject such a course of action would have dire consequences. As Maung Aung Myoe has observed, "the 2008 constitution is essentially designed by the military to find its ruling partner in Myanmar politics" ${ }^{41}$ It was never designed to cede complete control of the government, let alone the country, to civilian politicians. To be effective, the current government must operate as a coalition comprising both military and civilian elements. Also, as Aung San Suu Kyi has often acknowledged, a genuinely democratic system of government cannot be introduced into Myanmar without the Tatmadaw's full agreement and active cooperation. ${ }^{42}$

\section{Coup Rumours}

Given the Tatmadaw's privileged position at the centre of Myanmar's political life, the enormous influence that it can wield, and the hold that Senior General Min Aung Hlaing appears to have over Aung San Suu Kyi and her government, a military takeover in the 
foreseeable future seems highly unlikely. Even so, rumours of an impending coup surface from time to time, exciting commentators both inside and outside the country.

In recent years, professional Myanmar-watchers have tended to be sceptical that the Tatmadaw harbours any intentions to take back direct political power, but they have considered the possibility. ${ }^{43}$ In 2013, for example, a few analysts put the likelihood of a military coup occurring over the next five years as high as 20 per cent. Others believed that the odds were much lower, but felt that a coup was still possible. ${ }^{44}$ Some observers argued that, notwithstanding President Thein Sein's surprisingly independent stance and broadbased reform programme, after 2011 the country was still effectively under military control, so the question of a coup did not arise. They felt that the 2008 Constitution - like the 1974 socialist Constitution before it - was simply a political device that permitted the generals to continue running Myanmar behind the façade of a quasi-civilian government. ${ }^{45}$ To them, Thein Sein's administration was a sham. In those circumstances, there would be no need for a coup, as the military leadership could simply manipulate the current system to get whatever it wanted.

This argument underestimated the extent of the political changes occurring in Myanmar at the time. It also failed to take full account of the independence shown by both President Thein Sein and Pyitthu Hluttaw Speaker Thura Shwe Mann. That said, given the military backgrounds of these two officials, and many others in the new administration, not to mention the USDP's complete dominance of the parliament, such a view was not without some justification. Since Aung San Suu Kyi and the NLD took office in early 2016, the claim that the government is simply a front for the Tatmadaw is no longer tenable. The political landscape is now much more complicated. Not surprisingly, the advent of an elected quasi-civilian administration has reawakened fears of a military takeover. Indeed, as internal security problems have grown, the government has faced mounting criticism over its poor performance, tensions within the NLD have risen and the working relationship between Aung San Suu Kyi and Senior General Min Aung Hlaing has shown signs of strain, such stories are being heard more often.

Over the past year, coup rumours have been triggered by several developments. In November 2016, for example, after Min Aung Hlaing made a public reference to the provisions of the Constitution covering states of emergency, this was interpreted as a veiled reference to an impending coup. Similar concerns were raised when 
the commander-in-chief described the Tatmadaw's political role to a gathering of European Union military chiefs, and told a National Defence College group that the armed forces would always have a role to play in Myanmar's national political life. ${ }^{46}$ Three terrorist bombings in Yangon in November 2016, and reports of an increase in the national crime rate, also prompted stories that the armed forces might step in to restore law and order. When the USDP, together with 12 other minor parties, called upon President Htin Kyaw to call a meeting of the NDSC, some observers saw the request as a sign that a military takeover was in the offing. According to yet another press report, the government's unwillingness, or inability, to protect civilians displaced by the military campaigns in northern Myanmar also heightened concerns about a coup. ${ }^{47}$

One particular incident that prompted a spate of coup rumours was the murder of prominent NLD lawyer and constitutional reformist $\mathrm{Ko} \mathrm{Ni}$ in January 2017. This incident is still shrouded in mystery, but it prompted several commentators to suggest that there were elements associated with the armed forces prepared to take extreme measures to prevent any challenges to the 2008 Constitution, and to subvert Aung San Suu Kyi's government. To back up this claim, these pundits pointed to the fact that a number of the suspects in the murder conspiracy had military backgrounds. Shortly after this incident, Larry Jagan alluded to Naypyidaw's failure to meet popular expectations and wrote that "many analysts and foreign businessmen fear that recent events in Myanmar have pushed the country to the verge of implosion... And it has once again brought the possibility of a military coup to the fore." ${ }^{48}$ A few months later, Jagan wrote that "Myanmar's military leaders are planning a coup." ${ }^{49}$ He said that "There is no doubt that the military top brass have prepared contingency plans to take over power, as they can under the constitution, if they deem it necessary." ${ }^{50}$

Conspiracy theorists have gone further and argued that the armed forces always had a secret plan to bring down Aung San Suu Kyi's government and install a new military regime. In their view, ever since the NLD took office the Tatmadaw has deliberately played a spoiling role, both to deny the new government a chance to establish itself and to persuade the Myanmar people that only a strong military regime can deliver the stability, predictability and economic growth that they want. ${ }^{51}$ These pundits believe that the generals are waiting for the government to collapse, and may be manufacturing security crises to tip it in that direction. The more incompetent the civilian government looks, the conspiracy theory 
goes, the greater will be the demand for a more decisive and efficient regime. According to this thesis, when the government starts to fail the Tatmadaw will step in and take back direct control of the country, with popular support. ${ }^{52}$

Such arguments, however, are unconvincing. They fail to recognize that the NLD inherited a host of serious challenges when it took office, which the generals know from their own time in government defy quick or easy solutions. Also, the NLD has been responsible for many of its own problems. It was ill-prepared to take power in 2016, and since then has not performed well. Aung San Suu Kyi's imperious leadership style and tendency to micromanage government business has contributed to its inability to make significant progress. In any case, any attempt to disrupt the government could backfire on the armed forces. It would sully their name and raise doubts about their commitment to security and stability. They would gain little from assassinating Ko Ni. Indeed, that incident has already raised questions about the competence of the country's police and intelligence agencies, which fall under the military-led Home Affairs Ministry. ${ }^{53}$

As Mary Callahan has observed, rumours of a coup have been greatly exaggerated. ${ }^{54}$ The various statements made by Min Aung Hlaing can be viewed "as less a pretext for a return to military control than the expression of a fundamental commitment by the military and its allies to the constitution that put the NLD in power and protects its position there". ${ }^{55}$ In addition, as Callahan states, there is little chance that the armed forces would contemplate a takeover of the government while it is fighting a new insurgency in the country's west and a full-fledged war against an alliance of ethnic armed groups in the north. Besides, the question has to be asked: why would the generals willingly burden themselves once again with the suite of complex political, economic, social and foreign policy problems that Aung San Suu Kyi and her government are currently having to grapple with? The Tatmadaw probably has contingency plans to use in the event of a major breakdown in law and order, but that would only be prudent, given the poor performance of the NLD government and the record of failed political transitions elsewhere in the world.

\section{Possible Intervention Triggers}

That is not to say, however, that there are no issues which might prompt the Tatmadaw to intervene more directly in Myanmar's 
internal affairs. The reasons why it might do this can be examined at the national, institutional and personal levels.

At the national level, the armed forces are deeply committed to Myanmar's sovereignty, unity and internal stability, as they judge such matters. These goals were encapsulated in the former military government's three "national causes" and have been enshrined in the 2008 Constitution. Any developments which threaten the country in these ways would greatly concern the military leadership and raise the possibility of intervention of some kind. The perceived external threat to Myanmar has greatly diminished since 2011, when the international community more or less embraced President Thein Sein and his reform programme. ${ }^{56}$ The NLD's election in 2015 was widely welcomed and further reduced the perceived threat from abroad. ${ }^{57}$ However, Myanmar has attracted strong criticism over the Rohingya crisis and there are still up to 100,000 armed men and women in the country who do not, or only begrudgingly, recognize Naypyidaw's authority. Some are actively waging guerrilla wars against the central government, while others remain armed and potentially dangerous. ${ }^{58}$

Also, civil unrest could erupt in Myanmar over a wide range of issues. As the International Crisis Group has written, further religious violence, fanned by Buddhist extremists, remains a strong possibility. ${ }^{59}$ There have also been protests over contentious issues such as land ownership, law reforms, press freedoms, wage levels, union membership, working conditions and the increased cost of living. Encouraged by a greater awareness of other countries, thanks in part to satellite television and the Internet, and the relaxation of various laws since the demise of the military government, strikes and demonstrations have increased. ${ }^{60}$ Dissatisfaction with the government is growing. These tensions have been exacerbated by declining international confidence in Aung San Suu Kyi and the NLD. Foreign direct investment is slipping, and with it the rate of economic growth. According to one foreign observer "the military top brass are convinced that ... Aung San Suu Kyi's government is failing, and it is only a matter of time when they will have to be the saviours." 61

At the institutional level, the armed forces would be concerned at any attempts to deny them their special place in national affairs. This is not only spelt out in the Constitution, but has been reaffirmed by Senior General Min Aung Hlaing on numerous occasions. ${ }^{62}$ Most military officers are intensely nationalistic and take seriously their perceived role as guardians of the country, with a special responsibility 
to step in and "save" Myanmar, if that was believed necessary. The military leadership is also likely to act if the Tatmadaw itself was under threat. For example, should the government or parliament drastically reduce the defence budget, or seriously try to restrict the armed forces' sources of off-budget income, there is likely to be trouble. The Tatmadaw would be particularly concerned if it felt it was being denied the men and materiel necessary to fulfil its duty to "safeguard the constitution" and counter internal and external security threats. The high command may not have been behind the murder of $\mathrm{Ko} \mathrm{Ni}$, but the accusations levelled against it were based on the widely-held belief that any attempts to weaken the Tatmadaw's grip on power, for example by amending the Constitution, would be answered by firm action.

At the personal level, the generals would be unhappy about any attempt to remove the clause in the Constitution that effectively grants military personnel immunity from prosecution for human rights violations committed under the former military government. Aung San Suu Kyi has repeatedly expressed her support for the Tatmadaw as an institution, reminding everyone that it was created by her father. She has declined to dwell on historical events or to seek retribution for past injuries, either to herself or others. This approach has been welcomed by the high command. A few junior officers and men may be sacrificed on the altar of public opinion from time to time, but if any NLD politicians, foreign activists or members of the international community revived efforts to put Myanmar military personnel on trial for past crimes, that would prompt a strong reaction. ${ }^{63}$ By the same token, any attempt to prosecute senior police or army officers for human rights violations, for example against the Rohingya community in Rakhine State, would be strongly resisted.

All that said, the Tatmadaw is not the institution it once was, and there are significant constraints on direct military intervention. There would inevitably be a strong reaction to a coup, both within the country and outside it. A coup could spark the internal unrest, and bring back the external threats, that the high command has been so keen to reduce through its guided democratic transition process. Also, given the 2015 election result, it would appear that Aung San Suu Kyi and the NLD enjoy considerable support in the ranks of the armed forces. The generals would need to weigh carefully the benefits of a takeover against the possibility that it could cause a serious breakdown in military discipline. There are doubtless some members of the armed forces who regret their loss of power, and 
take satisfaction from the NLD's current troubles. However, for the time being at least, the generals seem content to leave the difficult and messy business of governing to the NLD, while keeping a watchful eye on key areas of interest and reaping any rewards on offer.

\section{Looking to the Future}

One question often asked since 2011 has been: when will the Tatmadaw "return to barracks"? This reflects a widespread wish for a genuinely democratic civilian government in Myanmar, but it misses a vital point. The Tatmadaw has never seen itself as having separate military and political roles, with the first naturally having primacy over the second. Rather, it is deeply imbued with the idea that, since the country regained its independence in 1948, the armed forces have been responsible for holding the Union together, defeating its enemies - both foreign and domestic - and saving the country from internal chaos. The Tatmadaw also sees itself as the protector of Myanmar's dominant Buddhist culture. This has given rise to an abiding belief, strengthened by training and indoctrination programmes, of the importance of "national politics", as opposed to "party politics". It has also led to the conviction that the Tatmadaw has both a right and duty to supersede other state institutions if circumstances demand. ${ }^{64}$

A coup against Aung San Suu Kyi's government in the foreseeable future seems highly unlikely. The generals do not want to run Myanmar again - at least not directly. They are determined to protect the Tatmadaw, its prerogatives and central place in national life. For this, they will continue to rely on the 2008 Constitution. They will also respond to any significant challenges (as they perceive them) to the country's unity, stability and sovereignty. The former regime's three "national causes" were always more than mere slogans. They were reflections of a deep commitment by the nationalistic armed forces leadership to certain core policies and values. These causes will be cited to justify further military operations against ethnic armed groups and the Rohingyas. They will also be used to explain the Tatmadaw's continuing political role. The modus vivendi between the civil and military authorities will not be an easy one, but broadly speaking the generals want the NLD government to succeed, as they share many of its goals. They too want Myanmar to be strong, modern, prosperous, stable, united, independent and respected. 
If the generals wished to cripple or even bring down the NLD government, as suggested by conspiracy theorists, then they have the means to do so. However, the only plan for which there is any evidence is the one that helped the NLD take office. That has largely been implemented. The argument that the generals wanted to see the NLD win power so that they could see it fail, demonstrating the inability of civilians to govern Myanmar, and perhaps to reveal Aung San Suu Kyi's personal shortcomings, is unconvincing. So too is the argument that the generals are deliberately trying to weaken the NLD government by creating security crises. That would defeat the purpose of the first plan. The generals can certainly be accused of being Machiavellian, but their main aim has been to step back from day to day government and allow a transition to a more democratic system, albeit one in which the Tatmadaw still exercises considerable influence. ${ }^{65}$ The NLD government's poor performance to date has doubtless convinced the generals that they were right to be cautious, and to retain control over the process.

The Tatmadaw is never going to willingly abandon a political role, but the generals hope to be able to extricate themselves from the routine of government. This will, however, take time. In 2003, when Prime Minister Khin Nyunt launched the seven-step roadmap, he did not specify a timeframe. However, he seemed to envisage a 10-15 year period before Myanmar could become a "guided democracy". This proved to be an accurate estimate. It may take a similar period of time before a genuine democracy is achieved, if indeed that ever proves possible. In his 2014 Armed Forces Day speech, for example, Senior General Min Aung Hlaing referred to the need for a "gradual reduction" in the Tatmadaw's political role as the country "matures in democracy". ${ }^{66}$ He has repeated this message on a number of occasions since the transfer of power to Aung San Suu Kyi's government in 2016. On other occasions, he has suggested that it may take another one or two five-year parliamentary terms for Myanmar to reach the stage at which power could be completely handed over to an elected civilian administration. ${ }^{67}$

The criteria for the level of "political maturity" sought by the Tatmadaw have never been spelt out, but clearly "stability and reconciliation" will be paramount concerns. That includes a nationwide peace settlement with the ethnic armed groups, but any such agreement will need to satisfy the Tatmadaw's abiding concerns about sovereignty, unity and stability.

At present, such an outcome seems a distant prospect. For example, the generals have described the operations of ethnic 
armed groups in the country's north as a challenge to Myanmar's sovereignty. They are also sceptical about the creation of a federal state, or one that accommodates independent fiefdoms. They insist that all non-state armed groups must lay down their arms before negotiations can begin in earnest, something that is unacceptable to most ethnic leaders. A collection of small military forces, under a rotating national leadership, as proposed by some ethnic organizations, is anathema to the Tatmadaw high command. Apart from their conviction that Myanmar must be one entity, have a strong central government and be protected by a single national military organization, the generals are conscious of the dangers of agreeing to a further transfer of power before all internal conflicts are resolved. ${ }^{68}$ They have seen how that has led to disaster in other countries, setting a very high bar for an enduring national peace settlement and, by extension, the transition to a full democracy.

Similarly, the Arakan Rohingya Salvation Army (ARSA) has been characterized by the Tatmadaw as a terrorist organization supported by foreign extremists, with the potential to stage attacks in Myanmar's cities, inflaming racial and religious tensions. ${ }^{69}$ In those circumstances, it is difficult to see the generals being prepared to further liberalize the government, let alone hand Myanmar over to a weak civilian administration. Indeed, by directly attacking the security forces, threatening a wider campaign of violence and raising the spectre of foreign interference in Myanmar's internal affairs, the ARSA has played into the hands of the more conservative members of the military hierarchy. ${ }^{70}$ The Rohingya conflict may have prompted widespread condemnation of the armed forces, mainly from the international community, but within Myanmar it seems to have enhanced the status of the Tatmadaw, reinforced its claim to be the guardians of the country and its Buddhist culture, and strengthened its domestic political influence.

Myanmar always has the capacity to surprise, which makes it difficult to predict what the future may hold. However, the outlook for the next four years is for more of the same, with Aung San Suu Kyi and the NLD government struggling to overcome their own weaknesses and the many other obstacles they face to deliver promised reforms. Some key policies, such as the negotiation of a nation-wide peace agreement with ethnic armed groups, will continue to encounter obstacles, not least the hard line favoured by the armed forces. Being largely dependent on the generals for security outcomes, there is also little chance that the government will be able to meet the international community's concerns over 
the plight of the Rohingyas. For, whatever happens, the armed forces will remain the ultimate arbiter of power in Myanmar and, as long as these and other issues remain unresolved, the country's transition to a full democracy will remain a remote prospect.

\section{NOTES}

$1 \quad$ An earlier version of this article appeared as Andrew Selth, All Going According to Plan? The Armed Forces and Government in Myanmar, Regional Outlook No. 54 (Brisbane: Griffith Asia Institute, 2017).

2 Andrew Selth, "Democracy in Myanmar: Who can take credit?", Myanmar Times, 31 March 2016, available at <http://www.mmtimes.com/index.php/opinion/19744democracy-in-myanmar-who-can-take-credit.html>.

3 See, for example, "Burma: US Should Retain Key Sanctions", Human Rights Watch, 6 September 2016, available at <https://www.hrw.org/news/2016/09/06/ burma-us-should-retain-key-sanctions $>$. For a different view, see Bryan Early, "Busting the myth that Myanmar is a sanctions success story", Policy Forum, 30 November 2016, available at <https://www.policyforum.net/busting-mythmyanmar-sanctions-success-story/>.

$4 \quad$ The Bangkok Post has claimed that the "seven-step roadmap to democracy" was the brainchild of Thai Prime Minister Thaksin Shinawatra. He encouraged the SPDC to find a way forward through the so-called "Bangkok Process", but the roadmap seems to have been entirely the regime's idea. See "In his own words: The rise and fall of Khin Nyunt", Bangkok Post, 9 April 2012, in BurmaNet News, available at <http://www.burmanet.org/news/2012/04/09/the-bangkok-postin-his-own-words-the-rise-and-fall-of-khin-nyunt/>.

5 Ben Dunant, "It's Good to Be the Tatmadaw", The Diplomat, 11 May 2017, available at <http://thediplomat.com/2017/05/its-good-to-be-the-tatmadaw/>.

$6 \quad$ Khin Nyunt, "We believe that we must give shape for emergence of democratic State that corresponds with our country and our people", New Light of Myanmar, 31 August 2003, available at <http://www.ibiblio.org/obl/docs/Roadmap-KN.htm>.

7 David Arnott, "Burma/Myanmar: How to read the generals' 'roadmap'- a brief guide with links to the literature", available at <http://www.ibiblio.org/obl/docs/ how10.htm>.

8 Constitution of the Republic of the Union of Myanmar (Naypyidaw: Ministry of Information, 2008).

9 "Western Election Observers Invited", Radio Free Asia, 21 March 2012, available at <http://www.rfa.org/english/news/myanmar/election-03212012170629.html>.

10 For example, at the ASEAN Summit in Kuala Lumpur in November 2015, all the other ASEAN leaders congratulated President Thein Sein on a successful "free and fair" election. See "Myanmar and ASEAN: Settling old scores", Frontier, 15 January 2016, available at <https://frontiermyanmar.net/en/opinion/ myanmar-asean-settling-old-scores $>$.

11 Moe Thuzar, "Myanmar's 2015 Elections: New Hope on the Horizon?", ISEAS Perspective, No. 70 (17 December 2015), available at $<$ https://www.iseas.edu. sg/images/pdf/ISEAS_Perspective_2015_70.pdf>. 
12 Constitution of the Republic of the Union of Myanmar, op. cit., Clause 58, p. 20. See also "Suu Kyi 'will be above president' if NLD wins Myanmar election", $B B C$ News, 5 November 2016, available at <http://www.bbc.com/news/worldasia-34729659>.

13 Robert Taylor, "Myanmar military preserves its autonomy, for now", Nikkei Asian Review, 16 March 2015, available at <http://asia.nikkei.com/Viewpoints/ Perspectives/Myanmar-s-military-preserves-its-autonomy-for-now $>$.

14 See, for example, Damien Kingsbury, "Why Myanmar's historic elections might not produce the results you think", $A B C$ News, 9 November 2015, available at <http://www.abc.net.au/news/2015-11-06/kingsbury-myanmars-historicelection/6918012>.

15 The two also reportedly spoke about the appointment of Chief Ministers of the States and Regions. "Aung San Suu Kyi could become Myanmar president after 'positive' talks - reports”, The Guardian, 8 February 2016, available at <https://www.theguardian.com/world/2016/feb/08/aung-san-suu-kyi-myanmarpresident-positive-talks>.

16 "Suu Kyi meets Myanmar's military chief again as transition talks drag on", Reuters, 17 February 2016, available at <http://www.reuters.com/article/usmyanmar-politics-idUSKCNOVQ160>.

17 Larry Jagan, "The lady and the generals are learning to get along", South Asian Monitor, 11 May 2017, available at <http://southasianmonitor.com/2017/05/11/ lady-generals-learning-get-along-2/>.

18 Feliz Solomon, "One Year On, Aung San Suu Kyi Struggles to Unite a Fractured Myanmar", Time, 30 March 2017, available at <http://time.com/4714808/myanmarburma-aung-san-suu-kyi-anniversary/>.

19 Alexis de Tocqueville, The Old Regime and the Revolution (New York: Harper and Brothers, 1856), p. 214.

May Wong, "Myanmar to 'wait and see' on constitutional change: Army chief", video and transcript, Channel NewsAsia, 21 January 2015.

${ }^{21}$ "Myanmar Army Chief Pushes Against Quick Changes to the Constitution", Voice of America, 23 February 2016, available at <https://www.voanews.com/a/ myanmar-army-chief-pushes-against-quick-changes-to-constitution/3203264.html>.

22 Htoo Thant, “'State Counsellor' bill approved despite military voting boycott”, Myanmar Times, 5 April 2016, available at <http://www.mmtimes.com/index. $\mathrm{php} /$ national-news/19844-military-protests-but-parliament-passes-state-counsellorbill.html>. Constitution of the Republic of the Union of Myanmar, op. cit., Clause 58, p. 20.

Prashanth Parameswaran, "What's Behind Myanmar's New National Security Adviser Post?", The Diplomat, 11 January 2017, available at <http://thediplomat. com/2017/01/whats-behind-myanmars-new-national-security-adviser-post/>.

25 The main source of foreign intelligence and assessments of Myanmar's strategic environment has long been the Foreign Ministry, not the military intelligence apparatus, which has focused more on domestic threats. See Andrew Selth, "Burma’s Intelligence Apparatus", Intelligence and National Security 13, no. 4 (Winter 1998): 33-70. 
26 "Political parties call for Intervention by NDSC", Mizzima News, 30 November 2016, available at <http://www.mizzima.com/news-domestic/political-parties-callintervention-ndsc $>$.

27 See, for example, Andrew Selth, "Why Myanmar's military is not planning a coup”, Nikkei Asian Review, 8 May 2017, available at <https://asia.nikkei.com/ Viewpoints/Andrew-Selth/Why-Myanmar-s-military-is-not-planning-a-coup>.

"All levels of government administration are under authority of the military chief”, Myanmar Now, 1 February 2016, available at <http://www.myanmar-now. org/news/i/?id=a79df810-6294-4c7e-b12e-5dbed993505e $>$.

Robert H. Taylor, "Discord, not devotion, will help Aung San Suu Kyi succeed", Nikkei Asian Review, 30 March 2017, available at <http://asia.nikkei.com/ Viewpoints/Robert-H.-Taylor/Discord-not-devotion-will-help-Aung-San-Suu-Kyisucceed $>$.

"Myanmar/Burma Update, 15-16 March 2013", ANU College of Asia and the Pacific, available at <http://asiapacific.anu.edu.au/sites/default/files/myanmar/ MBU-flyer.pdf>.

$31 \quad$ Renaud Egreteau, “A Generals' Election in Myanmar”, The Diplomat, 4 November 2015, available at <http://thediplomat.com/2015/11/a-generals-election-inmyanmar/>.

32 Prashanth, Parameswaran, “What Does Myanmar's New Defence Budget Mean?”, The Diplomat, 3 March 2017, available at <http://thediplomat.com/2017/03/ what-does-myanmars-new-defense-budget-mean/>. See also "Deficit rises, social spending deferred in 2017-18 budget proposal", Frontier Myanmar, 1 February 2017, available at <http://frontiermyanmar.net/en/deficit-rises-social-spendingdeferred-in-2017-18-budget-proposal >.

33 Michael Peel, "Myanmar: The military-commercial complex", Financial Times, 2 February 2017, available at <https://www.ft.com/content/c6fe7dce-d26a-11e6b06b-680c49b4b4c0?mhq5j=e1>.

34 See, for example, "All the Civilians Suffer": Conflict, Displacement, and Abuse in Northern Myanmar (London: Amnesty International, 2017), available at $<$ https://static.amnesty.org.au/wp-content/uploads/2017/06/Myanmar-report-FINALVERSION.pdf?x85233>.

$35 \quad$ Lun Min Mang, "Tatmadaw sets out peace conference position”, Myanmar Times, 16 May 2016, available at <http://www.mmtimes.com/index.php/national-news/ 20303-tatmadaw-sets-out-peace-conference-conditions.html>.

36 Liam Cochrane, “Myanmar's army may have killed 'thousands' of Rohingya Muslims", $A B C$ News, 9 February 2017, available at <http://www.abc.net.au/ news/2017-02-09/myanmar-may-have-killed-thousands-of-rohingya-muslims/ 8256344>. See also Peter Baker and Nick Cumming-Bruce, "US Threatens to Punish Myanmar Over Treatment of Rohingya", New York Times, 23 October 2017, available at <https://www.nytimes.com/2017/10/23/world/asia/rohingyabangladesh-myanmar.html>.

37 Oliver Holmes, "Nobel laureates warn Aung San Suu Kyi over 'ethnic cleansing' of Rohingya", The Guardian, 30 December 2016, available at <https://www. theguardian.com/world/2016/dec/30/nobel-laureates-aung-san-suu-kyi-ethniccleansing-rohingya>. 
"Aung San Suu Kyi rejects UN inquiry into crimes against Rohingya”, The Guardian, 3 May 2017, available at <https://www.theguardian.com/world/2017/ may/03/aung-san-suu-kyi-rejects-un-inquiry-into-crimes-against-rohingya>. See also Nick Cumming-Bruce, "U.N. Rights Council to Investigate Reports of Atrocities in Myanmar", New York Times, 24 March 2017, available at <https:// www.nytimes.com/2017/03/24/world/asia/myanmar-rakhine-rohingya-un-rightscouncil.html>.

Andrew Selth, “Strong, Fully Efficient and Modern”: Myanmar's New Look Armed Forces, Regional Outlook Paper No. 49 (Brisbane: Griffith Asia Institute, 2015), available at <https://www.griffith.edu.au/_data/assets/pdf_file/0008/777878/ Regional-Outlook-Paper-49-Selth.pdf $>$.

Andrew Selth, Burma's Security Forces: Performing, Reforming or Transforming?, Regional Outlook Paper No. 45 (Brisbane: Griffith Asia Institute, 2013), available at <https://www.griffith.edu.au/__data/assets/pdf_file/0011/559127/RegionalOutlook-Paper-45-Selth.pdf>.

Maung Aung Myoe, "Partnership in Politics: The Tatmadaw and the NLD in Myanmar since 2016”, presentation to the 2017 Myanmar Update Conference, Australian National University, 17 February 2017.

42 Jared Genser, "Democracy on a leash”, US News, 12 November 2015, available at $<$ https://www.usnews.com/opinion/blogs/world-report/2015/11/12/the-militarywill-still-control-myanmar-after-aung-san-suu-kyis-victory>.

43 "Myanmar and coups", ANU College of Asia and the Pacific, 16 August 2013, available at <http://asiapacific.anu.edu.au/news-events/all-stories/myanmar-andcoups $>$.

44 Joshua Kurlantzick and Devin T. Stewart, "Burma's Reforms and Regional Cooperation in East Asia”, Carnegie Council for Ethics in International Affairs, Summer 2013, available at <http://www.carnegiecouncil.org/publications/ articles_papers_reports/0164.html/:pf_printable>.

45 Bertil Lintner, “The Military's Still in Charge”, Foreign Policy, 9 July 2013, available at <http://www.foreignpolicy.com/articles/2013/07/09/the_militarys_ still_in_charge $>$.

“In EU Meeting, Min Aung Hlaing Defends Army’s Political Role”, The Irrawaddy, November 2016, available at <https://www.irrawaddy.com/opinion/ commentary/in-eu-meeting-min-aung-hlaing-defends-armys-political-role.html>.

47 Mary Callahan, "Fears of a military coup are exaggerated", Nikkei Asian Review, 14 December 2016, available at <https://asia.nikkei.com/Viewpoints/MaryCallahan2/Fears-of-military-coup-in-Myanmar-are-exaggerated>.

Larry Jagan, "Who killed Ko Ni? Assassination leaves Myanmar on the verge of implosion", South Asian Monitor, 14 February 2017, available at <http:// southasianmonitor.com/2017/02/14/killed-ko-ni-assassination-leaves-myanmarverge-implosion/>. Jagan, "The lady and the generals are learning to get along", op. cit. Jagan, “Who killed Ko Ni?”, op. cit.

51 Author interviews with analysts, commentators and members of the public in Yangon and Mandalay, February 2017. 
52 Andrew Selth, "The Lady and authoritarianism in Myanmar", Nikkei Asian Review, 29 March 2016, available at <http://asia.nikkei.com/Viewpoints-archive/ Viewpoints/Andrew-Selth-The-Lady-and-authoritarianism-in-Myanmar>.

53 Jagan, "Who killed Ko Ni?”, op. cit.

${ }_{54}$ Callahan, "Fears of a military coup in Myanmar are exaggerated", op. cit.

55 Ibid.

56 Andrew Selth, Burma and the Threat of Invasion: Regime Fantasy or Strategic Reality?, Regional Outlook Paper No. 17 (Brisbane: Griffith Asia Institute, 2008), available at <http://www.griffith.edu.au/business/griffith-asia-institute/pdf/ Andrew-Selth-Regional-Outlook-17.pdf>.

57 The argument that Myanmar's democratic transition stems mainly from a fear of China over-simplifies a very complex process. See Jonathan T. Chow and Leif-Eric Easley, "Persuading Pariahs: Myanmar's Strategic Decision to Pursue Reform and Opening”, Pacific Affairs 89, no. 3 (September 2016): 521-42.

58 Senior General Min Aung Hlaing has described the campaigns in Rakhine State, Kachin State and Shan State in 2016 as battles to preserve Myanmar's sovereignty. See Pyae Thet Phyo, "Sen-Gen Min Aung Hlaing calls for military modernisation", Myanmar Times, 28 March 2017, available at <http://www. mmtimes.com/index.php/national-news/nay-pyi-taw/25471-sen-gen-min-aunghlaing-calls-for-military-modernisation.html>.

59 Buddhism and State Power in Myanmar, Report No. 290 (Yangon/Brussels: International Crisis Group, 5 September 2017), available at <https://www. crisisgroup.org/asia/south-east-asia/myanmar/290-buddhism-and-state-powermyanmar>.

60 Andy Buschmann, "Does the data reveal declining dictatorship in Myanmar?", New Mandala, 27 February 2017, available at <http://www.newmandala.org/ data-reveal-declining-dictatorship-myanmar/>.

61 Jagan, “Who killed Ko Ni?”, op. cit.

62 Anne Gearan, "Burma's Thein Sein says military 'will always have a special place' in government”, Washington Post, 19 May 2013, available at <http:// articles.washingtonpost.com/2013-05-19/world/39376769_1_president-obamathan-shwe-sanctions>. See also Lawi Weng, "In Naypyidaw, Suu Kyi Attends Armed Forces Day", The Irrawaddy, 27 March 2013, available at <http://www. irrawaddy.org/archives/30671>.

63 See, for example, Charlie Campbell, "Top Legal Academics Want Burmese Generals Indicted for War Crimes”, Time, 7 November 2014, available at $<$ http:// time.com/3571709/harvard-law-school-burma-myanmar-war-crimes/>.

${ }_{64}$ Robert H. Taylor, The Armed Forces in Myanmar Politics: A Terminating Role?, Trends in Southeast Asia No. 2 (Singapore: Institute of Southeast Asian Studies, 2015).

65 Kyaw Ye Lynn, "Military playing ‘cunning’ game in Myanmar”, Anadolu Agency, 31 March 2017, available at <http://aa.com.tr/en/asia-pacific/military-playingcunning-game-in-myanmar/784887>.

66 Myanmar's Military: Back to the Barracks?, Asia Briefing No. 143 (Yangon/ Brussels: International Crisis Group, 22 April 2014), available at <https:// d2071andvip0wj.cloudfront.net/myanmar-s-military-back-to-the-barracks.pdf>. 
67 Guy Dinmore, "Democratic transition to take years, general says", Myanmar Times, 21 July 2015, available at <http://www.mmtimes.com/index.php/nationalnews/nay-pyi-taw/15590-democratic-transition-to-take-years-general-says.html>.

"Amid transition, Myanmar's Senior General Min Aung Hlaing emerges from the shadows", South China Morning Post, 26 February 2016, available at $<$ http://www.scmp.com/news/asia/southeast-asia/article/1917067/amid-transitionmyanmars-senior-general-min-aung-hlaing >.

69 "Army, Govt Warn of Militant Attacks on Cities", The Irrawaddy, 5 September 2017, available at <https://www.irrawaddy.com/news/burma/army-govt-warnmilitant-attacks-cities.html>.

70 See “The Rakhine State Danger to Myanmar's Transition”, Statement/Asia (Yangon/Brussels: International Crisis Group, 8 September 2017), available at $<$ https://www.crisisgroup.org/asia/south-east-asia/myanmar/rakhine-state-dangermyanmars-transition>. 